\title{
Accounting for the Drivers that Degrade and Restore Landscape Functions in Australia
}

\author{
Richard Thackway ${ }^{1, *}$ and David Freudenberger ${ }^{2}$ \\ 1 School of Geography, Planning and Environmental Management, University of Queensland, \\ Brisbane, QLD 4072, Australia \\ 2 Fenner School of Environment \& Society, Australian National University, Linnaeus Way, \\ Acton, ACT 2601, Australia; david.freudenberger@anu.edu.au \\ * Correspondence: r.thackway@uq.edu.au; Tel.: +61-426-258-361
}

Academic Editors: Jeffrey Sayer and Chris Margules

Received: 25 July 2016; Accepted: 4 November 2016; Published: 12 November 2016

\begin{abstract}
Assessment and reporting of changes in vegetation condition at site and landscape scales is critical for land managers, policy makers and planers at local, regional and national scales. Land management, reflecting individual and collective values, is used to show historic changes in ecosystem structure, composition and function (regenerative capacity). We address the issue of how the resilience of plant communities changes over time as a result of land management regimes. A systematic framework for assessing changes in resilience based on measurable success criteria and indicators is applied using 10 case studies across the range of Australia's agro-climate regions. A simple graphical report card is produced for each site showing drivers of change and trends relative to a reference state (i.e., natural benchmark). These reports enable decision makers to quickly understand and assimilate complex ecological processes and their effects on landscape degradation, restoration and regeneration. We discuss how this framework assists decision-makers explain and describe pathways of native vegetation that is managed for different outcomes, including maintenance, replacement, removal and recovery at site and landscape levels. The findings provide sound spatial and temporal insights into reconciling agriculture, conservation and other competing land uses.
\end{abstract}

Keywords: land management; ecosystem structure; composition; function; tracking change; monitoring; reporting; anthropogenic; transformation; plant communities; vegetation

\section{Introduction}

Landscapes are dynamic through time, and changes can be efficiently tracked by monitoring the removal, replacement, enhancement or restoration of native vegetation cover. Such dynamics are related to social, economic and political drivers, as well as environmental drivers, such as climate variation. Landscapes are often transformed by intentional or inadvertent management practices that alter native vegetation cover, variously fragmenting it into a matrix of altered states [1-3]. Knowledge of how land management practices are used by local communities to modify and replace native vegetation over time, coupled with landscape genesis and climate variables, can be used to generate predictable pathways for native vegetation recovery (resilience) at sites and landscape scales [4]. This information provides a critical understanding essential for facilitating desired landscape scale change.

For this paper, we ambitiously set ourselves the task of describing and understanding circa 250 years of landscape transformation pathways of native ecosystems from case studies in 10 contrasting ago-climatic regions of Australia. We demonstrate and discuss the value of using a systematic and comprehensive chronology of land management practices and their impacts on vegetation structure, composition and function to document and illustrate the interaction of people 
living in, learning from and adapting to their environment. We note the value of using a repeatable framework to quantify landscape dynamics over centuries to provide a strong understanding of historical legacies and insights into ecosystem resilience and active restoration. We focus on the benefits of systematically applying this framework to provide rigorous and consistent information for land use planners, policy makers and land managers by elucidating the drivers of such landscape changes. We demonstrate that the condition of landscapes at key points in time is an emergent property of economic markets, the history of settlement, environmental constraints, government policies and programs and the impact of individual land manager's practices and values. We discuss our findings in light of the landscape management principles of Sayer and others [5]; particularly multiple scales; clarification of rights and responsibilities; and resilience. We discuss the theoretical and practical underpinning of how land management effects and changes ecosystem resilience over time [4].

In Australia, landscape transformation is usually assessed relative to a pre-1750 reference state, i.e., at the time of European settlement, or the start of the Industrial Revolution [6]. This date is prior to European settlement, in 1788, and thus reflects the pre-European land-use status, which although not without substantial human effects on the landscape, had been relatively stable for many tens of thousands of years of Aboriginal land use [7,8].

We use the Vegetation Assets States and Transition (VAST) framework [3,9], as a site to landscape assessment tool to critically appraise the relevance of scientific studies, reports and historical knowledge of on-ground practice to document and account for changes in vegetation structure, composition and function. We aimed to demonstrate that the VAST methodology can contribute to a collective learning spiral [10] that may facilitate individuals, communities and government agencies to better understand ecosystem resilience and effectively improve landscape function to deliver a variety of desired ecosystem services [11].

Our premise of applying the VAST methodology is that it can result in improved understanding and management of the key functional, structural and compositional components of the ecosystem at a site or landscape scale relative to its reference state. We argue that within the limits imposed by regional climate and microclimates, the recovery of native ecosystems largely depends on restoring landscape function (e.g., soil structure, hydrology and nutrient cycling), vegetation structure and compositional diversity. The natural disturbance regime, e.g., fire, droughts and floods, must also be documented and understood to effectively manage landscapes sustainably.

We demonstrate that site-based assessments of the effects that local land managers have on indicators of vegetation condition can be up-scaled to generate a whole of landscape perspective. Examples of how the VAST framework has been used to generate national assessments of change in the extent and condition of ecosystems include Australia [2] and Israel [12].

\section{Method}

\subsection{Selecting Case Study Sites to Represent Australia's Agro-Climatic Regions}

Ten sites were selected, with one site being assigned to each of 10 agro-climatic regions we have delineated across Australia [13,14] (Figure 1; refer also to Tables S1 and S2 in the Supplementary Material).

At a national scale, there is broad correspondence between agro-climatic regions $[13,14]$ and agro-ecological regions [15], regarding associated patterns of land use and management and both native and human-managed vegetation.

At the international level, agro-climatic categories correspond reasonably well to the primary and secondary Köppen divisions of the 10 global agro-climatic categories [16], but at the finer landscape scale, there are obvious differences in detail [14]. For this reason, we selected a modified form of Australia's 10 agro-climatic regions [13] to provide a broad stratification to assess the extent to which local individuals and communities have been transforming landscapes over the past 250 years. 


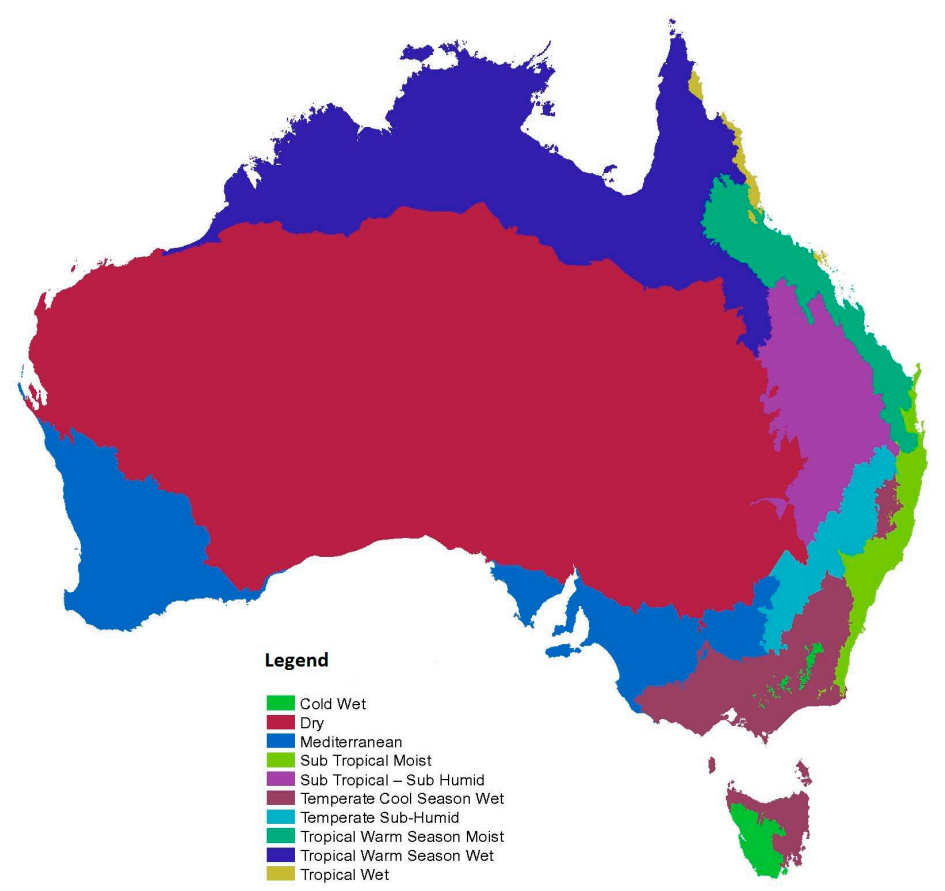

(a)

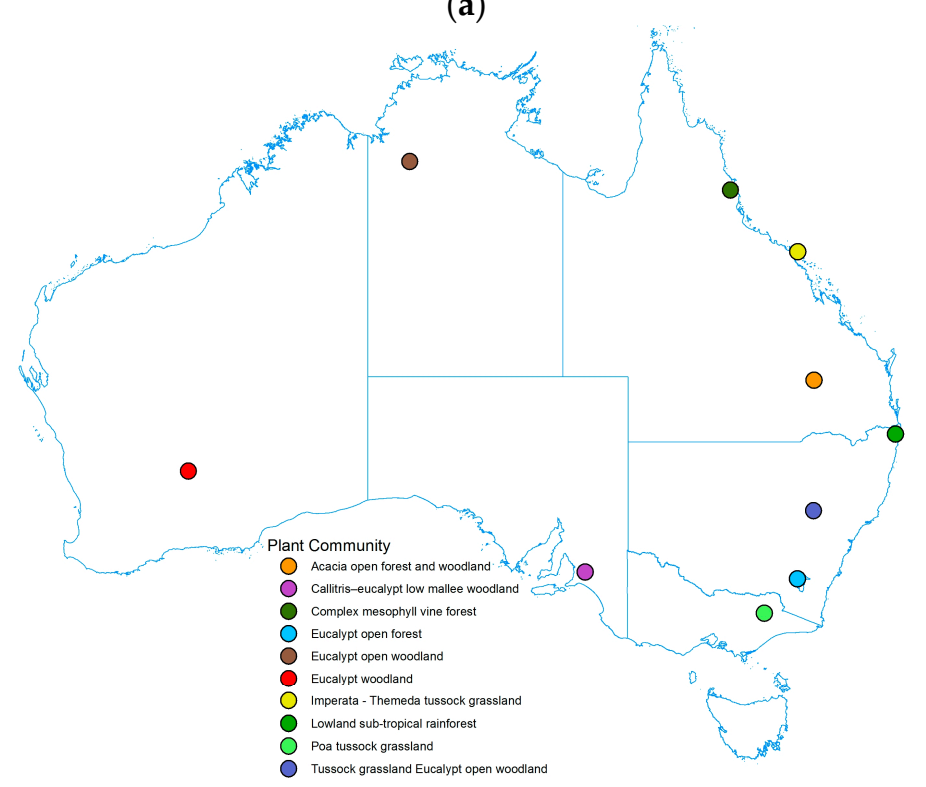

(b)

Figure 1. (a) Extent of the 10 agro-climatic regions; and (b) location of the 10 sites and the associated plant community type (refer to Tables S1 and S2 in the Supplementary Material).

We acknowledge that plant community responses will differ between different agro-climatic regions and that no two plant community types will have the same responses to different land management practices (i.e., resilience of ecosystems) over time. It follows that the categories of indicators (structure, composition and function) [17] can be the same for all landscapes, while the actual indicators are tied to place.

The 10 agro-climatic regions are described using characteristics of climate, pre-European native vegetation and current land use for each region (refer to Table S2 in the Supplementary Material). Each of the 10 sites is considered typical of the soil-landscape associations, plant communities, land use and management histories of each agro-climatic region. 
We merged the agro-climatic regions [13,14] and the agro-ecological regions [15] to derive the regionalisation shown in Figure 1a. We adopted the labels and most of the boundaries of the agro-ecological regions [13] and integrated these with the ecological descriptions of climate, topography, vegetation and land use of the agro-ecological regions [15]. We modified the boundary of the dry and tropical warm season wet agro-climate regions [13] to correspond to the southern extent of the Australian tropical savannas [18]. This boundary adjustment was done acknowledging that Region $\mathrm{H}$ was described as an ecotone between tropical warm season wet and the dry continental region [14]. We delimited a revised northern boundary of the dry agro-climate region by using the northern extent of Region G [14]. An added reason for modifying the boundary of the dry and tropical warm season wet agro-climate regions is because, since the 1970s, the rainfall pattern has changed across the tropical savannas. Generally, more rain has been received in the summer period, and the wet season has extended beyond the previously-accepted patterns of summer dominant rains into the autumn period. This change has coincided with a general increase in the cover and density of woody tree cover across the tropical savannas $[18,19]$.

\subsection{A Framework for Assessing Change}

The VAST framework [2,9] was used as a tool for consistently and repeatedly assessing the effects that land management practices have on the structure, composition and function of plant communities over time. The hierarchical framework of VAST-2 captures the key stages of the degradation and recovery of ecosystem processes that affect vegetation communities modified by human activity.

Detailed chronologies were compiled for each site using a plotless sampling unit, i.e., a soil-landscape association, the location and general extent of which remains unchanged over time. The dimensions of the site are georeferenced as a centroid, which remains constant back in time, now and into the future.

For each site, we used the 10 criteria and 22 indicators (Table 1) of VAST-2 as a checklist to search for and compile relevant spatio-temporal sources of data and information over time to generate a systemic and comprehensive site history. Sources of information included: published and unpublished accounts, scientific surveys, long-term ecological monitoring sites, land manager interviews, remote sensing and public-private data archives [9]. Our literature review included what is known about the unmodified or reference state plant community type for each site, which is described by the same 10 criteria and 22 indicators. Indicators from the reference state were used in a relative sense to assess the transformation of each site over time.

We also used the 10 criteria and 22 indicators to assess the response of each plant community to the effects of the management practices. This process involved integrating and evaluating the site-based environmental histories and the response of the plant community over space and time. The integration of the relative difference between the transformation of a site and its reference state determined the relative effects that land management practices have had on vegetation condition and resilience over time. An aggregate index for each year in the chronology of a site is scored across four levels in a hierarchy (Table 1) [9].

We compiled and assessed the response of the plant community at each site in terms of structure, composition and function in response to land management regimes and practices. Therefore, it was necessary to define and describe land management regimes (or actions/interventions), as shown in Table 2. We then classified the responses of plant communities to these regimes based on how the practices of each regime individually and collectively transform the indicators of vegetation structure, composition and function over time. Collectively, the outcomes of these regimes are variously the maintenance, enhancement, restoration, degradation and or removal and replacement of a particular plant community at a site and or landscape.

We make a distinction between the reference state and a contemporary baseline. Most environmental monitoring and tracking of the responses of plant communities seek to measure and observe change relative to a current baseline. The VAST framework readily compiles and 
synthesises such data and information, where the attribute data being measured can be directly related to the fully-natural reference state for the criteria and indicators listed in Table 1.

Table 1. List of Vegetation Assets States and Transition (VAST) indicators, criteria and components of vegetation condition [9] used in this paper. Change is assessed relative to an assumed pre-European benchmark. A fourth level results in a vegetation status or transformation index derived by adding the weighted scores from Level 3.

\begin{tabular}{|c|c|c|}
\hline $\begin{array}{l}\text { Condition } \\
\text { Components }\end{array}$ & $\begin{array}{l}\text { Key Functional, Structural } \\
\text { and Composition Criteria }\end{array}$ & Indicators \\
\hline Level 3 & Level 2 & Level 1 \\
\hline \multirow{12}{*}{ Functional } & \multirow{2}{*}{ Soil hydrology } & Rainfall infiltration and soil water holding capacity \\
\hline & & Surface and subsurface flows \\
\hline & \multirow[b]{2}{*}{ Soil physical status } & Effective rooting depth of the soil profile \\
\hline & & $\begin{array}{l}\text { Bulk density of the soil through changes to soil structure or } \\
\text { soil removal }\end{array}$ \\
\hline & \multirow{2}{*}{ Soil nutrient status } & Nutrient stress: rundown (deficiency) relative to reference soil fertility \\
\hline & & Nutrient stress: excess (toxicity) relative to reference soil fertility \\
\hline & \multirow{2}{*}{ Soil biological status } & $\begin{array}{l}\text { Organisms responsible for maintaining soil porosity and } \\
\text { nutrient recycling }\end{array}$ \\
\hline & & Surface organic matter, soil crusts \\
\hline & \multirow[t]{2}{*}{ Natural disturbance regime } & $\begin{array}{l}\text { Area/size of disturbance events: foot prints (e.g., major storm cells, } \\
\text { floods, wildfire, cyclones, droughts, ice) }\end{array}$ \\
\hline & & Interval between disturbance events \\
\hline & \multirow{2}{*}{ Reproductive potential } & Reproductive potential of overstorey structuring species \\
\hline & & Reproductive potential of understorey structuring species \\
\hline \multirow{6}{*}{ Structural } & \multirow{3}{*}{ Overstorey structure } & Overstorey top height (mean) of the plant community \\
\hline & & Overstorey foliage projective cover (mean) of the plant community \\
\hline & & $\begin{array}{l}\text { Overstorey structural diversity (i.e., a diversity of age classes) } \\
\text { of the stand }\end{array}$ \\
\hline & \multirow{3}{*}{ Understorey structure } & Understorey top height (mean) of the plant community \\
\hline & & Understorey ground cover (mean) of the plant community \\
\hline & & $\begin{array}{l}\text { Understorey structural diversity (i.e., a diversity of age classes) } \\
\text { of the plant }\end{array}$ \\
\hline \multirow{4}{*}{ Compositional } & \multirow[b]{2}{*}{ Overstorey composition } & Densities of overstorey species functional groups \\
\hline & & $\begin{array}{l}\text { Richness: the number of indigenous overstorey species relative to the } \\
\text { number of exotic species }\end{array}$ \\
\hline & \multirow[b]{2}{*}{ Understorey composition } & Densities of understorey species functional groups \\
\hline & & $\begin{array}{l}\text { Richness: the number of indigenous understorey species relative to } \\
\text { the number of exotic species }\end{array}$ \\
\hline
\end{tabular}

${ }^{1}$ Modified from the functional, structural and compositional levels of organization observed in biological diversity [17].

Table 2. Five land management regimes used to evaluate the response of a native plant community to land management practices, relative to the reference state.

\begin{tabular}{l} 
Management Regimes \\
\hline 1. No active intervention that affects indicators of vegetation function, structure and composition \\
\hline $\begin{array}{l}\text { Management practices that harvest vegetation products (biomass, fibre, flowers, fruit and nuts), which affect } \\
\text { indicators of vegetation function, structure and composition }\end{array}$ \\
\hline 3. Management practices that enhance or improve indicators of vegetation function, structure and composition \\
\hline 4. Management practices that extirpate or remove indicators of the function, structure and composition \\
\hline 5. Management practices that reconstruct or reinstate indicators of the function, structure and composition \\
Modified from [20].
\end{tabular}


The VAST system also presents a simple graphical report card showing the drivers of change and trend relative to a reference state (i.e., natural benchmark). Existing reference states were obtained from published sources or were elicited from skilled local ecologists and botanists [9]. The graph represents a transformation trajectory for a plant community where the condition (i.e., vegetation status) is scored out of a potential $100 \%$ (i.e., an unmodified reference state). The total score is comprised of three weighted components: function (regenerative capacity; $55 \%$ weighting); vegetation structure ( $27 \%$ weighting); and species composition $18 \%$ [9]. This weighting was applied in the same manner across all case studies. The total vegetation status score was calibrated to the six VAST classes [2], enabling the broad description of types of changes in condition over time. The degree of divergence between the reference state and the vegetation scores over time for each case study represents the degree of modification. Scores are grouped according to the following intervals:

$80 \%-100 \%$ of the reference state corresponds to a residual/unmodified state;

$60 \%-80 \%$ corresponds to a modified state;

$40 \%-60 \%$ corresponds to a transformed state;

$20 \%-40 \%$ corresponds to VAST Class IV: replaced and adventive; as well as

$0 \%-20 \%$ corresponds to VAST Class V: replaced and managed; and VAST Class VI: replaced.

These five intervals provide a meaningful basis for describing and summarising change.

\section{Results}

The 250-year dynamics and drivers of the vegetation condition of case studies from the 10 agro-climatic regions of Australia are summarised in Table 3. These dynamics and drivers are graphically shown in Figures 2-11.

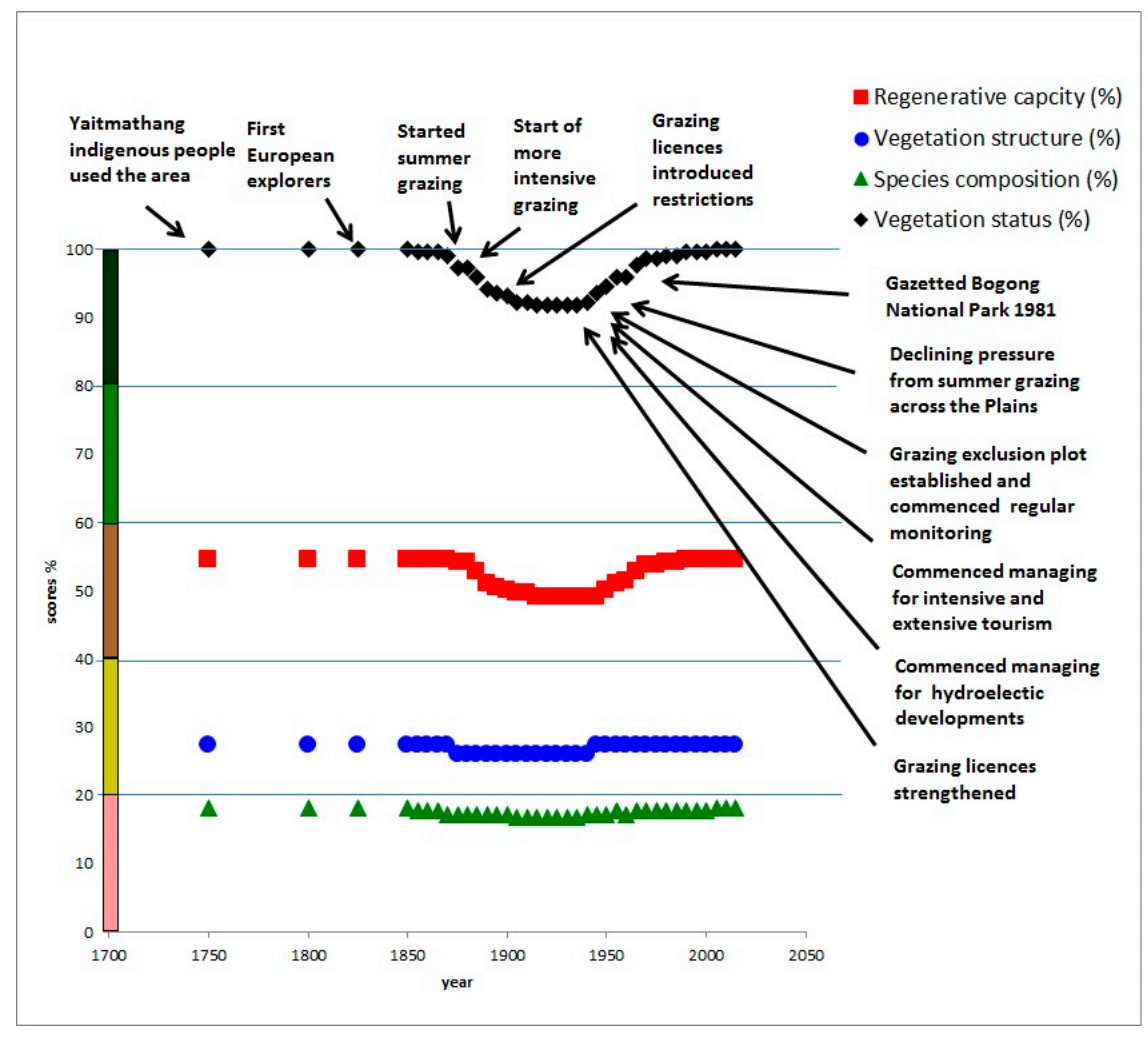

Figure 2. Case Study 1: Rocky Valley, Bogong High Plains, cold wet agro-climate region, Poa tussock grassland. 


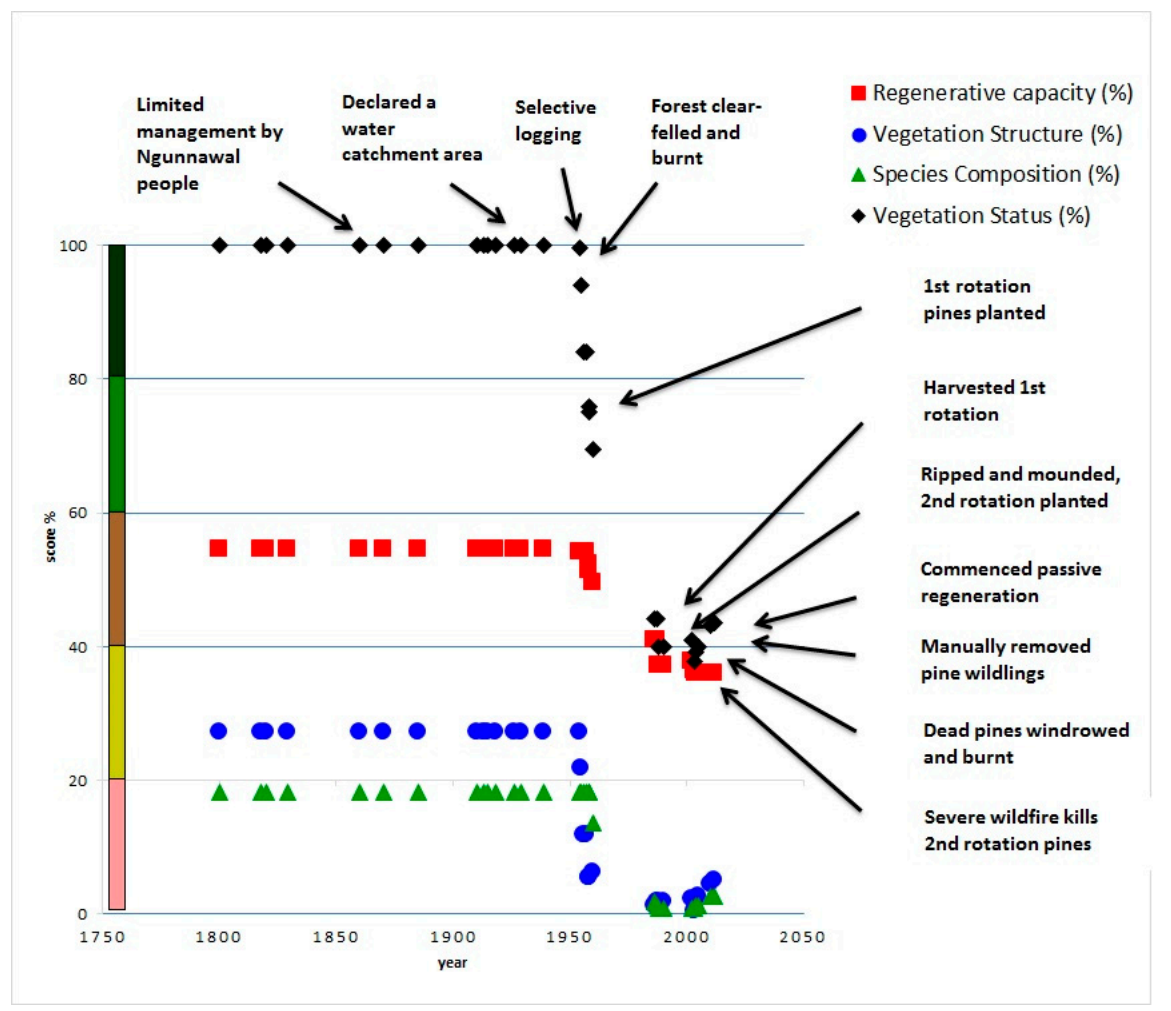

Figure 3. Case study 2: Blundells Flat, Brindabella Range, temperate cool-season wet agro-climate region, eucalypt open forest.

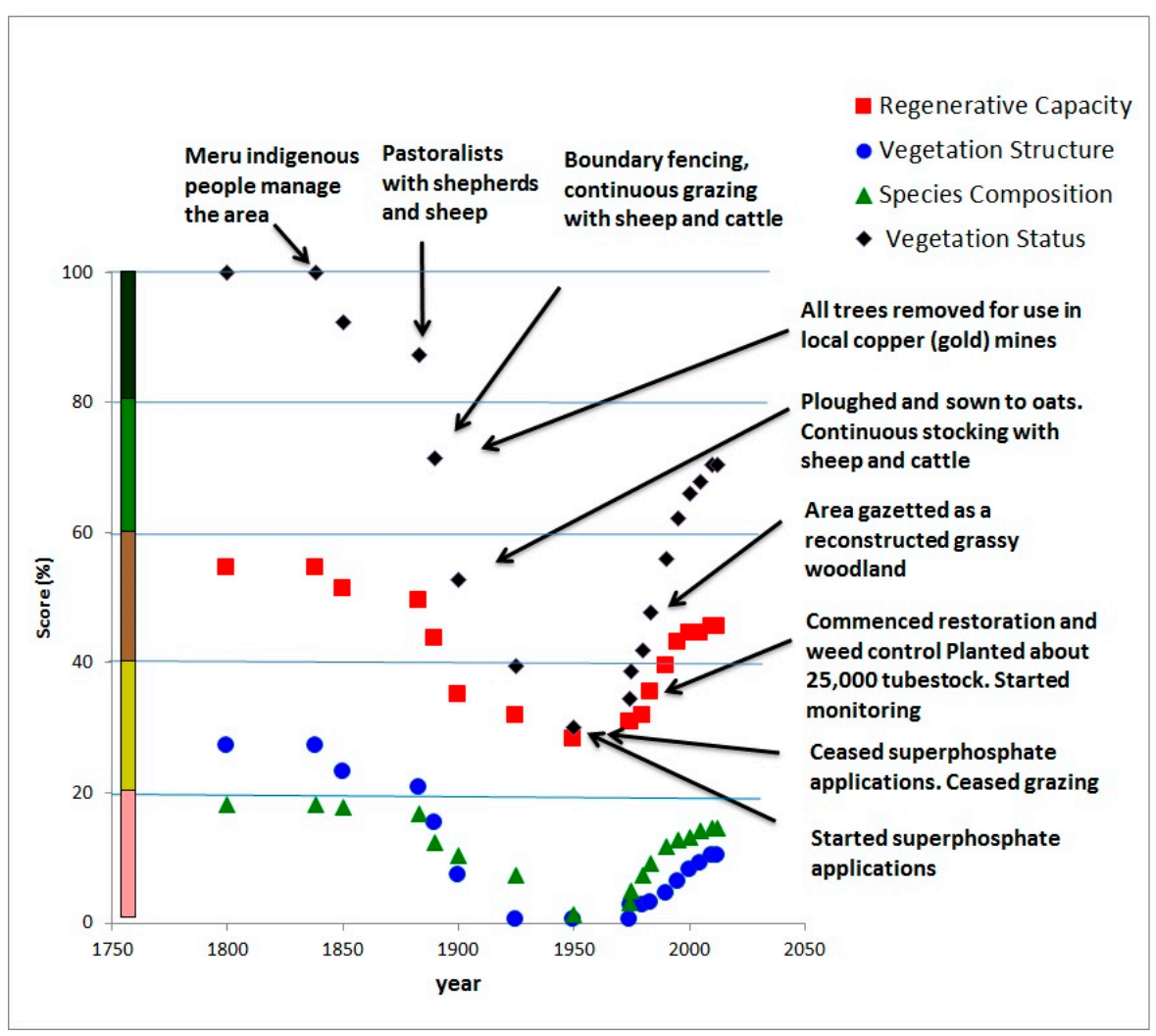

Figure 4. Case study 3: Wirilda, Harrogate, Mediterranean agro-climate region, Callitris, eucalypt low mallee woodland. 


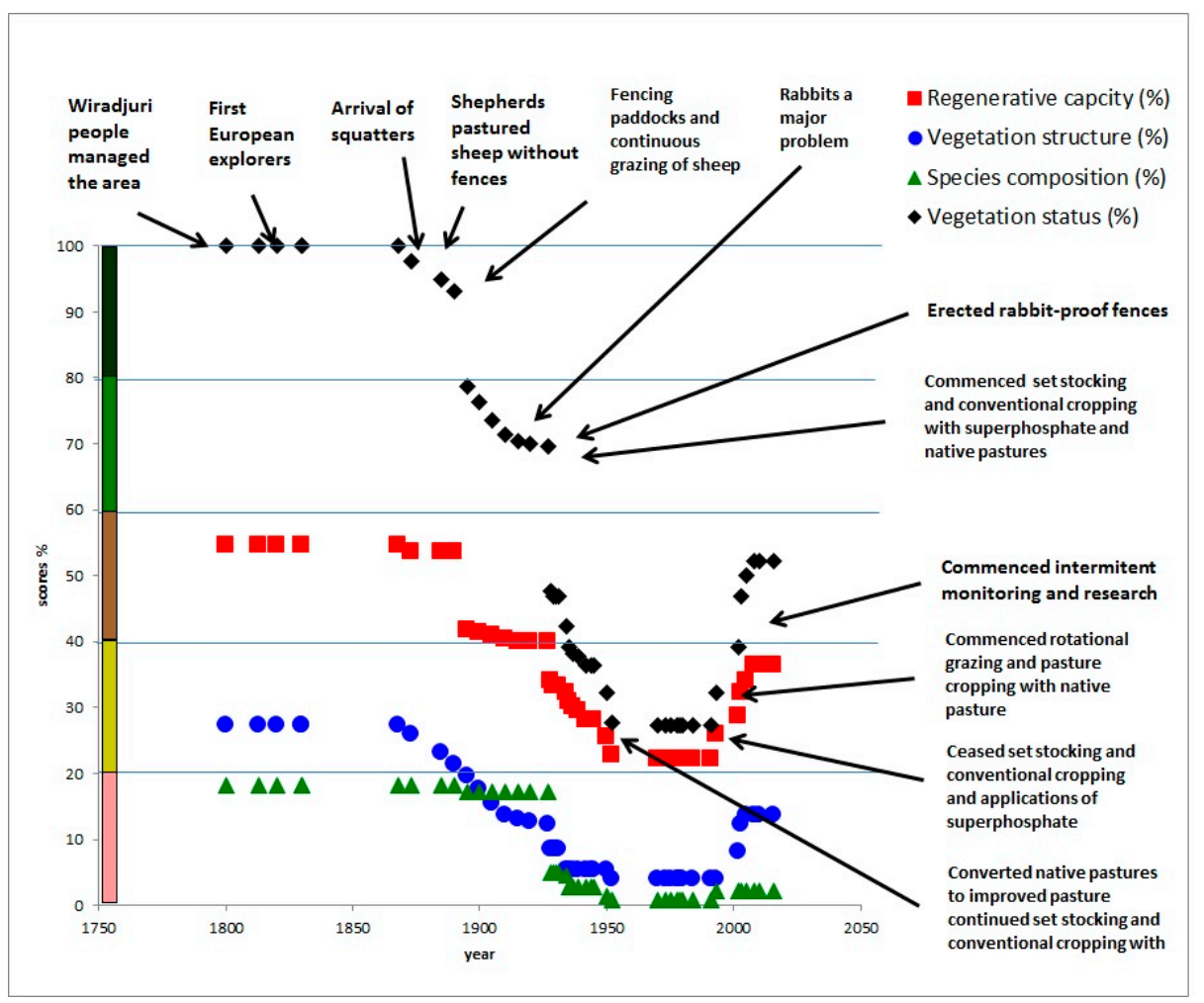

Figure 5. Case study 4: Winona, Gulgong, temperate, sub-humid agro-climate region, tussock grassland, eucalypt open woodland.

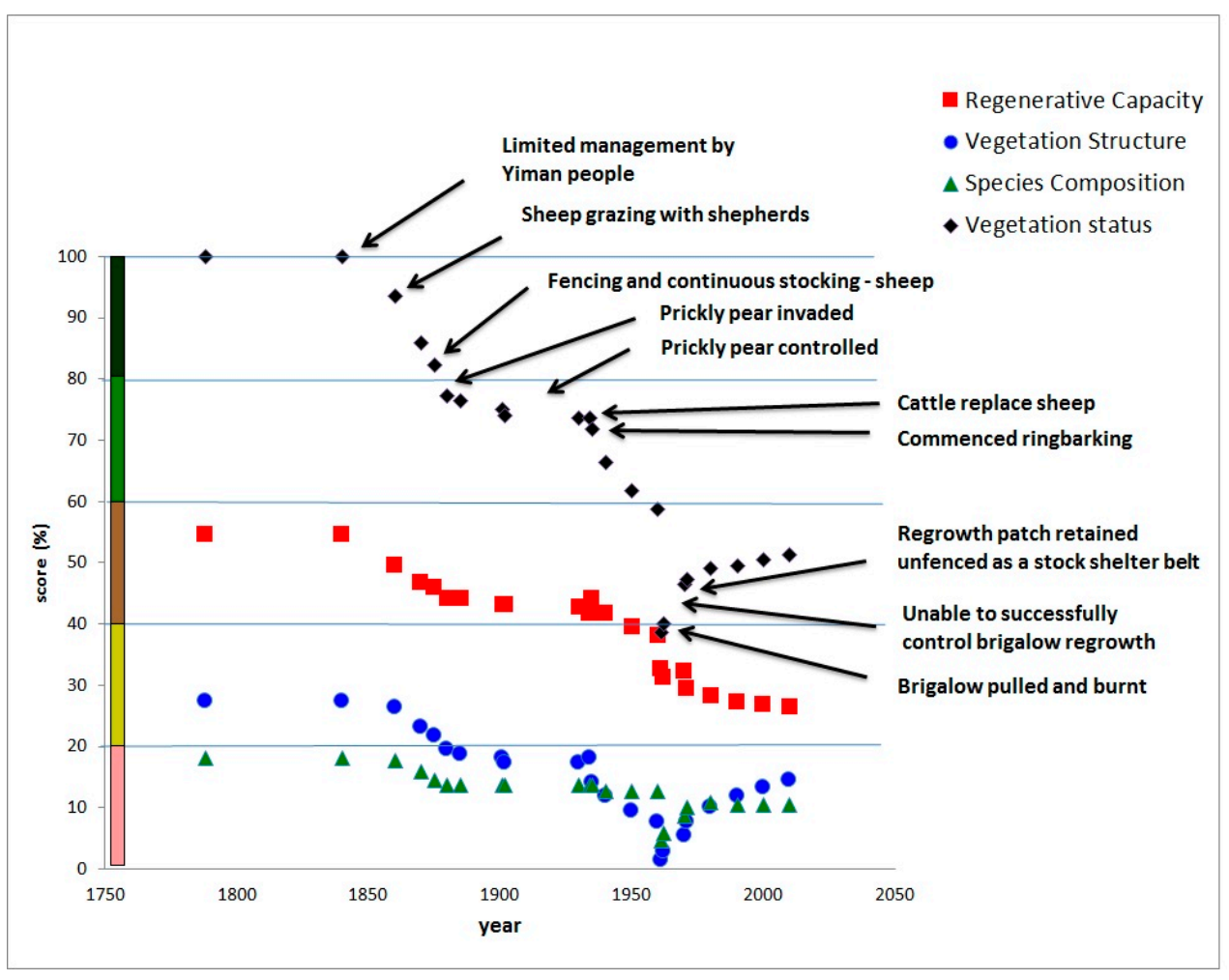

Figure 6. Case study 5: Potters Flat, Wandoan, sub-tropical sub-humid agro-climate region, Acacia open forest and woodland. 


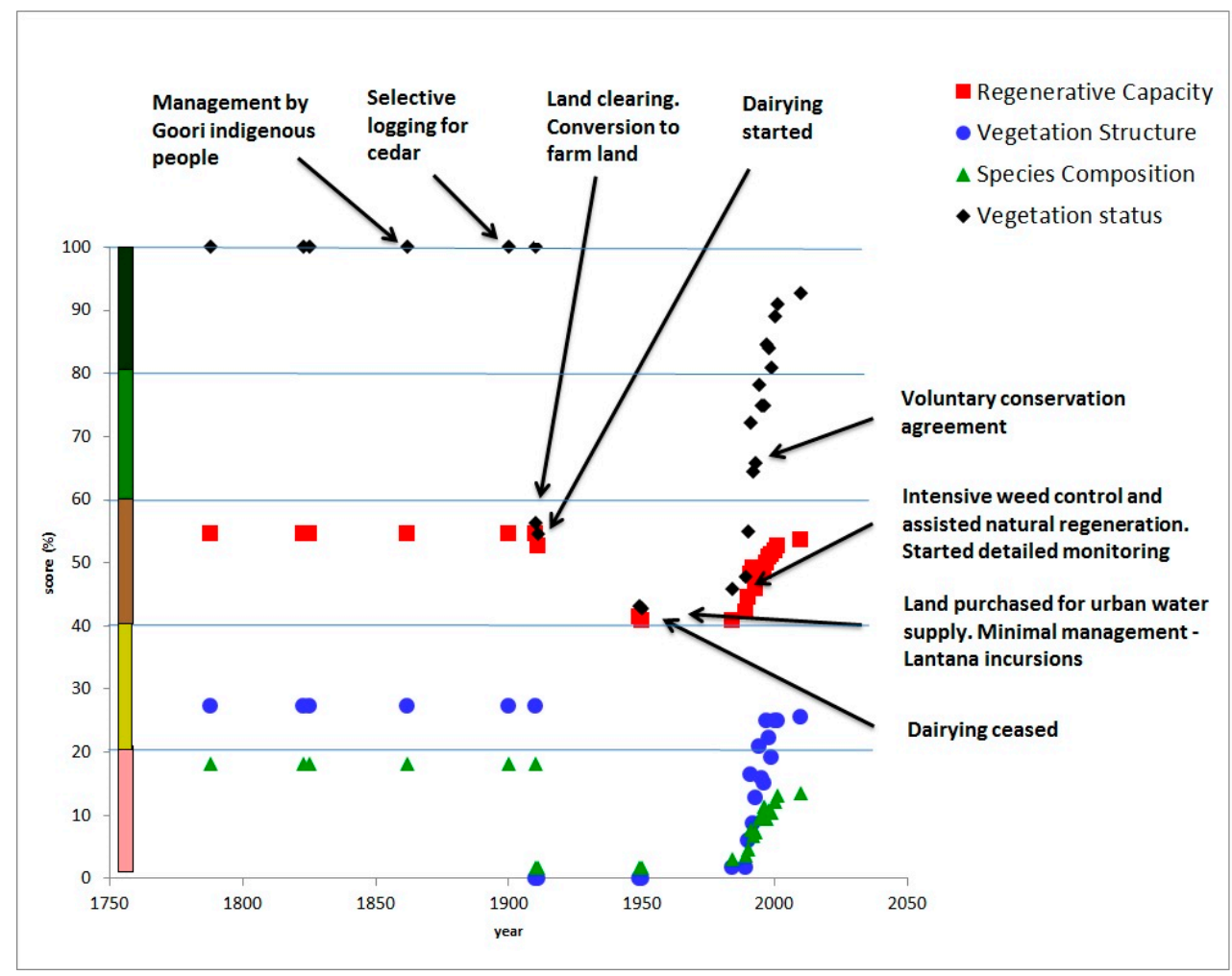

Figure 7. Case study 6: Rocky Creek Dam, Big Scrub, sub-tropical moist agro-climate region, lowland sub-tropical rainforest.

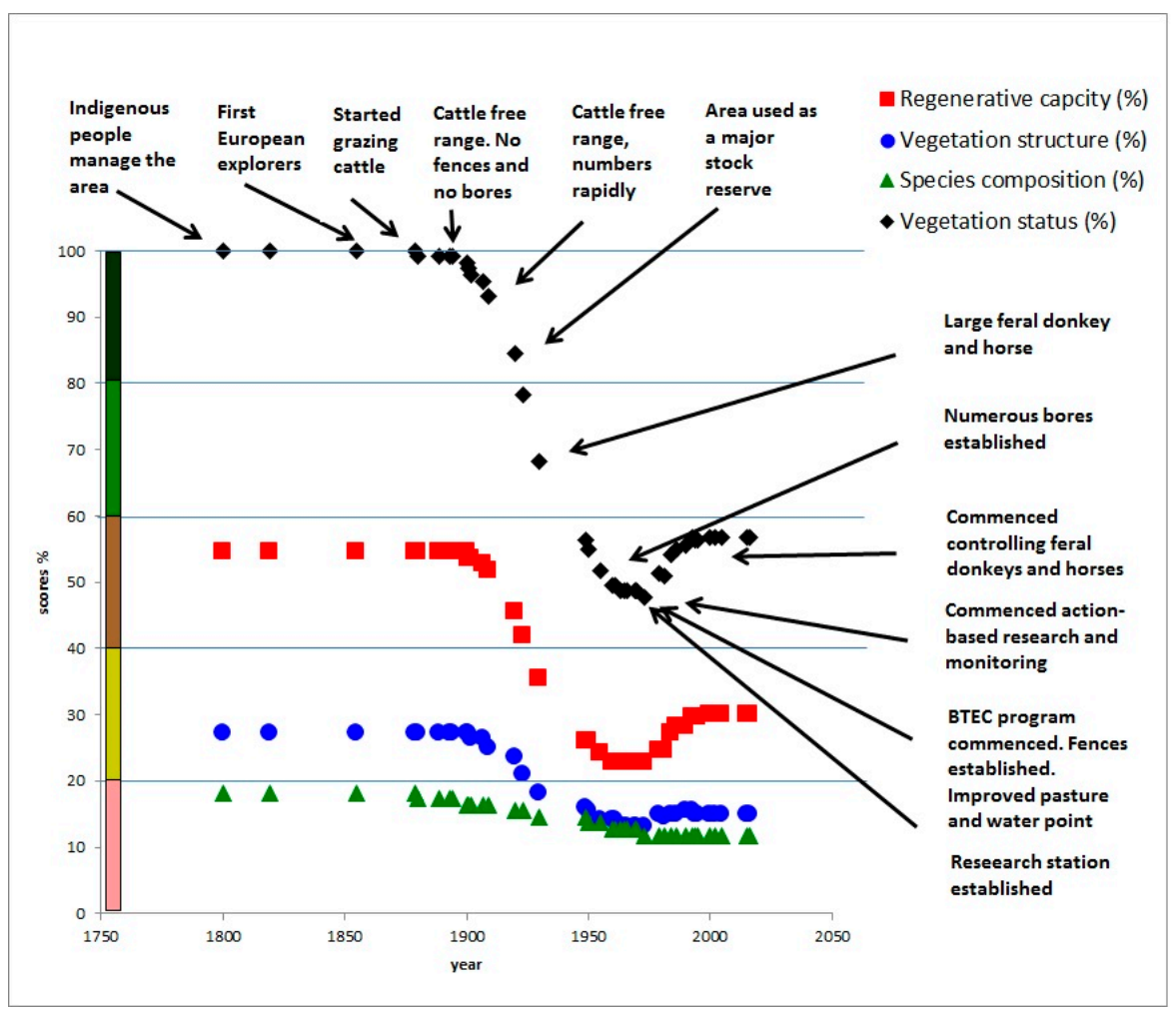

Figure 8. Case study 7: Conkerberry Paddock, Victoria River Research Station, tropical warm season wet agro-climate region, eucalypt open woodland. 


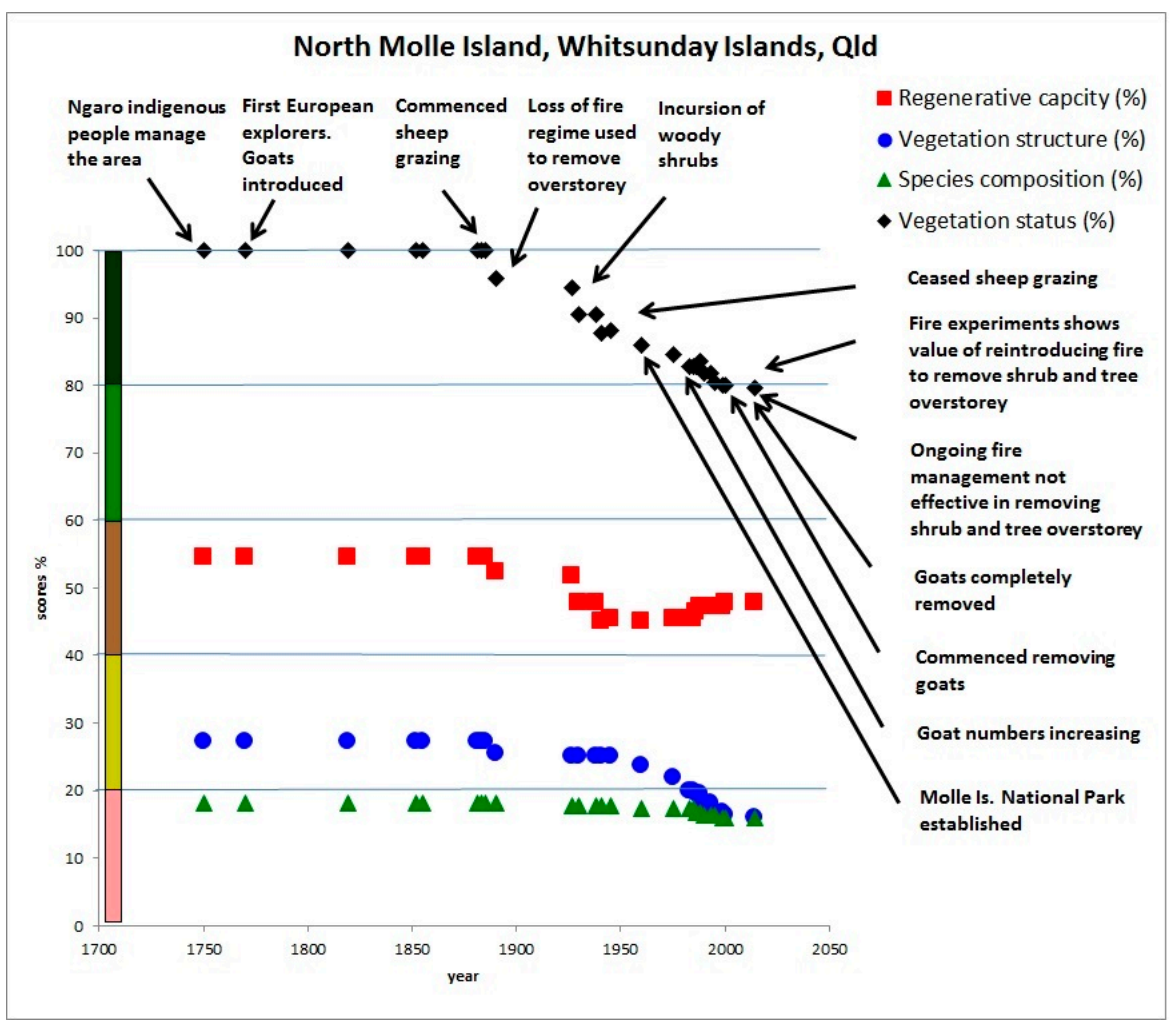

Figure 9. Case study 8: North Molle Island, Molle Group, Cumberland Islands, tropical warm season moist agro-climate region, Imperata and Themeda tussock grassland.

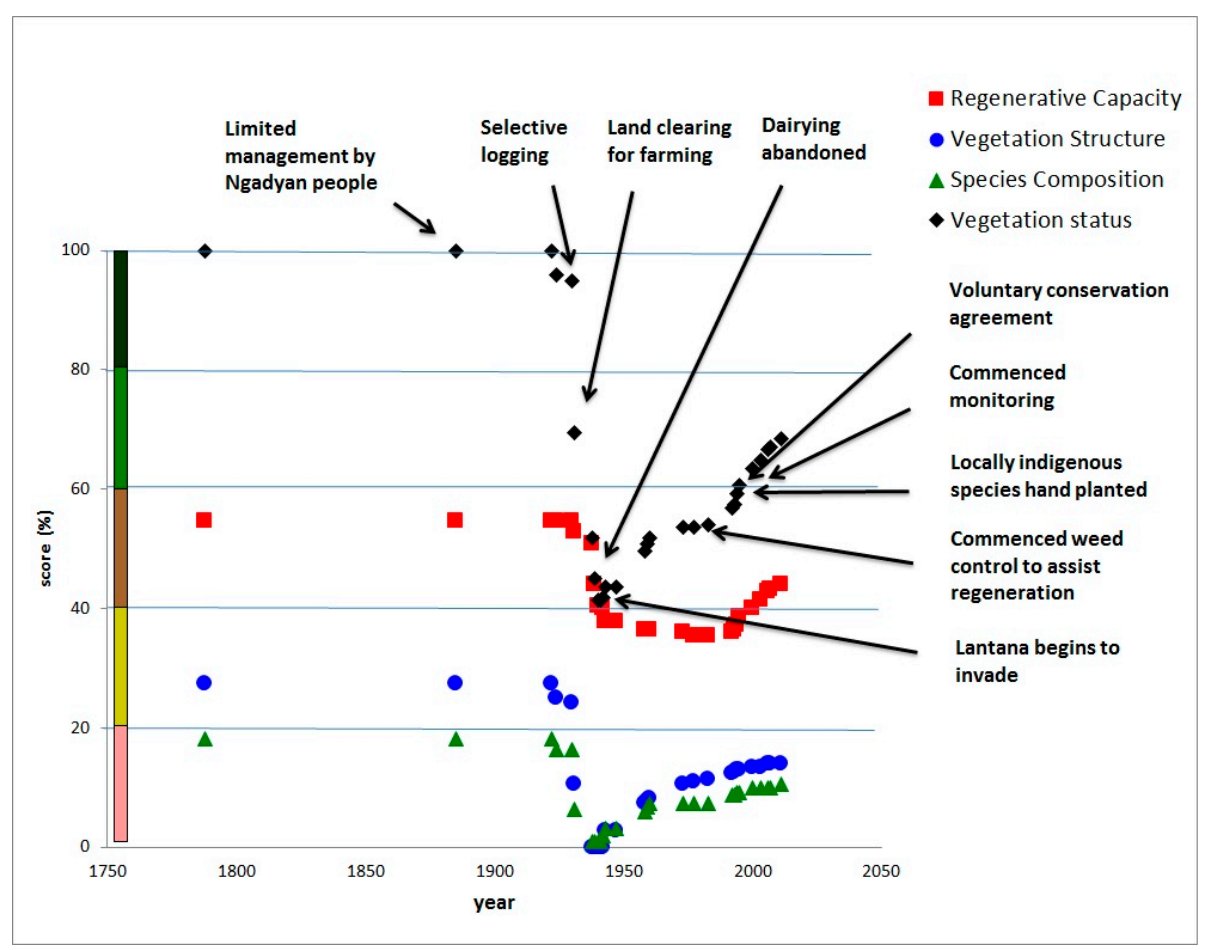

Figure 10. Case study 9: Wooroonooran Nature Refuge, tropical wet agro-climate region, complex mesophyll vine forest. 


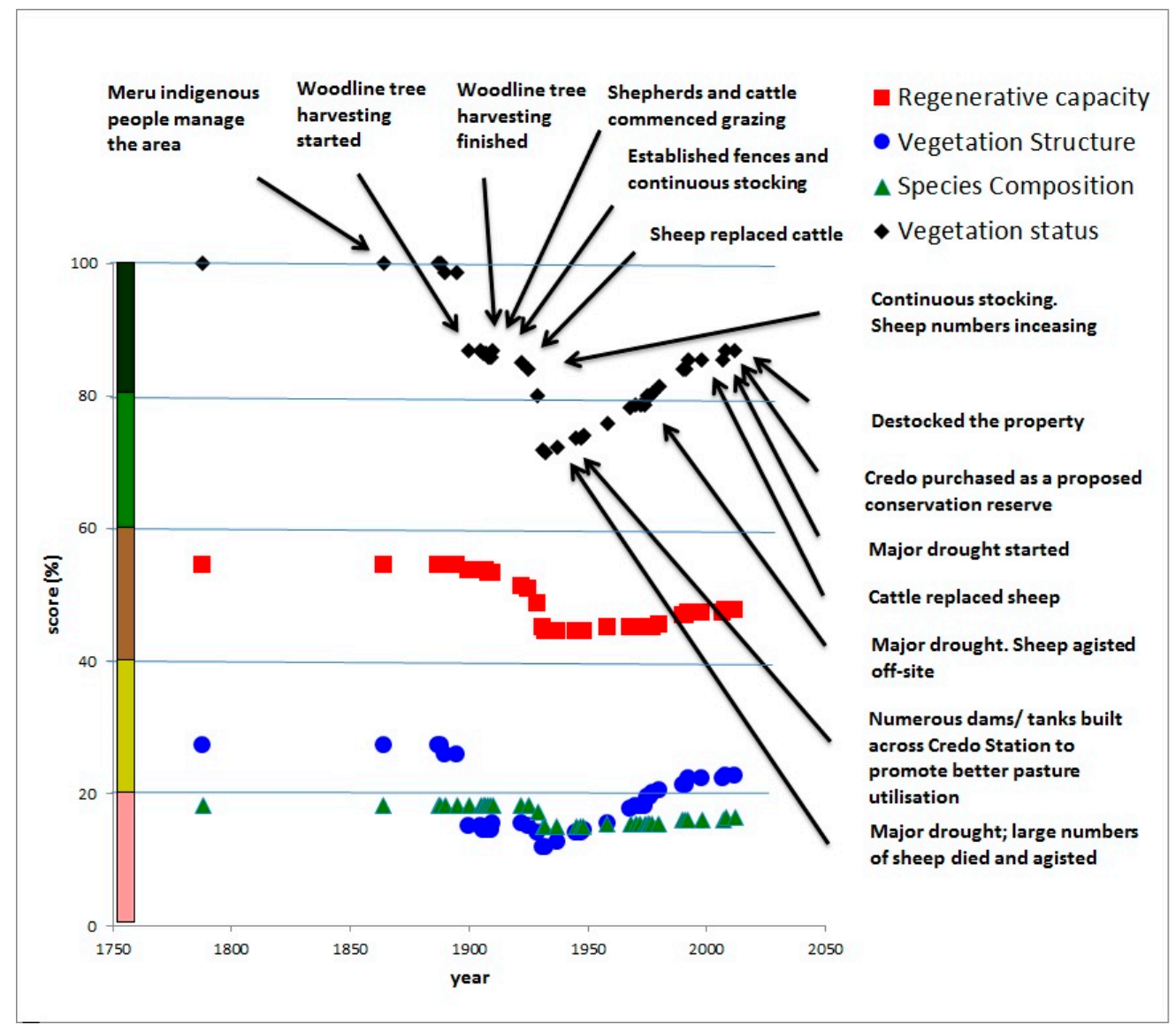

Figure 11. Case study 10: Chadwin paddock, Credo Station, dry agro-climate region, eucalypt woodland.

Detailed descriptions and explanations of each case study are provided in the Supplementary Material.

These results illustrate the dominant transformation pathways that have affected much of the Australian continent. These transformations include processes of replacement, removal and recovery of natural ecosystems; noting that native vegetation is used as an integrating surrogate for ecosystems. The responses of the 10 case studies illustrate different influences that individuals, local communities, government policies, markets and climate variation have had in reducing vegetation composition, structure and function. Though in half of the cases (Figures 2, 4, 5, 7 and 9), there has been recent and substantial restoration of composition, structure and regenerative capacity of the local native vegetation. The one common and profound driver of loss of vegetation condition for all of these case studies has been the rapid and near complete displacement of indigenous communities and land management practices by people, technology and land management practices of recent European origins.

Figures $2-11$ show the total vegetation status score calibrated to VAST classes: $80 \%-100 \%$ of the reference state corresponds to VAST Class I: residual/unmodified (dark green bars); $60 \%-80 \%$ corresponds to VAST Class II: modified (mid-green bars); $40 \%-60 \%$ corresponds to VAST Class III: transformed (brown bars); $20 \%-40 \%$ corresponds to VAST Class IV: replaced and adventive (lime green bars); $1 \%$ to $20 \%$ corresponds to VAST Class V: replaced and managed (pink bars); and $0 \%$ corresponds to VAST Class VI: replaced and removed (red bars, not relevant in these case studies). 
Table 3. Drivers of changes in vegetation conditions across representative case studies from Australia's ago-climatic zones based on Figures 2-11 and case study descriptions provided in Tables S1 and S2 in the Supplementary Material.

\begin{tabular}{|c|c|c|c|c|c|c|c|}
\hline $\begin{array}{l}\text { Case } \\
\text { Study }\end{array}$ & $\begin{array}{l}\text { Agro-Climatic } \\
\text { Zone and } \\
\text { Reference } \\
\text { Vegetation }\end{array}$ & $\begin{array}{c}\text { Vegetation Condition } \\
\text { Dynamics (Status Score } \\
\text { Change Relative to } \\
\text { Reference State) }\end{array}$ & Government Policies & Markets & Technological Changes & Climate Variation & Cultural \\
\hline 1 & $\begin{array}{l}\text { Cold-wet, } \\
\text { alpine grassland }\end{array}$ & $\begin{array}{l}10 \% \text { loss due to livestock } \\
\text { grazing then recovery to } \\
\text { near reference conditions }\end{array}$ & $\begin{array}{l}\text { State government reduction, then } \\
\text { prohibition of livestock grazing, } \\
\text { then creation of a national park }\end{array}$ & $\begin{array}{l}\text { Rapid development of } \\
\text { national and international } \\
\text { markets for meat and wool }\end{array}$ & Domestic livestock & $\begin{array}{l}\text { Periods of drought that } \\
\text { increased livestock } \\
\text { grazing pressure on } \\
\text { alpine grassland }\end{array}$ & $\begin{array}{l}\text { Total indigenous } \\
\text { displacement by Western } \\
\text { European values and land } \\
\text { management practices }\end{array}$ \\
\hline 2 & $\begin{array}{l}\text { Cold-wet, } \\
\text { open forest }\end{array}$ & $\begin{array}{l}60 \% \text { loss due to forest } \\
\text { clearing, minor recovery by } \\
\text { passive restoration }\end{array}$ & $\begin{array}{l}\text { National and territory } \\
\text { government-funded } \\
\text { establishment of softwood } \\
\text { plantations, then initiation of } \\
\text { restoration of native vegetation } \\
\text { for water catchment values }\end{array}$ & $\begin{array}{l}\text { Domestic market for } \\
\text { softwood for housing } \\
\text { construction now } \\
\text { influenced by softwood } \\
\text { supply from New Zealand }\end{array}$ & $\begin{array}{l}\text { Pinus radiata } \\
\text { plantation system }\end{array}$ & $\begin{array}{l}\text { Severe wildfire destroys } \\
\text { pine plantation in 2003, } \\
\text { linked to prolonged } \\
\text { drought, as well as periods } \\
\text { of above average rainfall } \\
\text { that supported passive } \\
\text { restoration (El-Nino-La } \\
\text { Nina cycles) }\end{array}$ & $\begin{array}{l}\text { Total indigenous } \\
\text { displacement by Western } \\
\text { European values and land } \\
\text { management practices }\end{array}$ \\
\hline 3 & $\begin{array}{l}\text { Mediterranean, } \\
\text { low (mallee) } \\
\text { woodland }\end{array}$ & $\begin{array}{l}70 \% \text { loss due to clearing, } \\
\text { then significant recovery by } \\
\text { active restoration }\end{array}$ & $\begin{array}{l}\text { Various regulations that required } \\
\text { clearing, then subsidies on } \\
\text { fertiliser to increase } \\
\text { intensification, more recently, } \\
\text { agri-environment schemes to } \\
\text { support farmers to restore } \\
\text { native vegetation }\end{array}$ & $\begin{array}{l}\text { Demand for timber for } \\
\text { smelting of copper, then } \\
\text { domestic and international } \\
\text { demand for meat wool } \\
\text { and grains }\end{array}$ & $\begin{array}{l}\text { Mining technology, } \\
\text { broad-scale cropping and } \\
\text { exotic pasture systems, } \\
\text { domestic livestock, fencing } \\
\text { and feral rabbits }\end{array}$ & $\begin{array}{l}\text { Periods of drought that } \\
\text { hastened loss of vegetation } \\
\text { condition, as well as periods } \\
\text { of above average rainfall } \\
\text { that supported restoration } \\
\text { (El-Nino-La Nina cycles) }\end{array}$ & $\begin{array}{l}\text { Total indigenous } \\
\text { displacement by Western } \\
\text { European values and land } \\
\text { management practices }\end{array}$ \\
\hline 4 & $\begin{array}{l}\text { Temperate, } \\
\text { sub-humid, grassy } \\
\text { eucalypt } \\
\text { woodland }\end{array}$ & $\begin{array}{l}70 \% \text { loss due to clearing } \\
\text { then partial recovery }\end{array}$ & $\begin{array}{l}\text { Various regulations that required } \\
\text { clearing, then subsidies on } \\
\text { fertiliser to increase } \\
\text { intensification, more recently, } \\
\text { later agri-environment schemes } \\
\text { to support farmers to restore } \\
\text { native vegetation }\end{array}$ & $\begin{array}{l}\text { Domestic and international } \\
\text { demand for grains, meat } \\
\text { and wool }\end{array}$ & $\begin{array}{l}\text { Broad-scale cropping and } \\
\text { exotic pasture systems, } \\
\text { domestic livestock, fencing } \\
\text { and feral rabbits; no till } \\
\text { cropping into dormant native } \\
\text { pasture with cell-based } \\
\text { sheep grazing }\end{array}$ & $\begin{array}{l}\text { Drought and wildfire were } \\
\text { a stimulus for land } \\
\text { management change } \\
\text { coupled with localised } \\
\text { rising ground water that } \\
\text { was saline. }\end{array}$ & $\begin{array}{l}\text { Total indigenous } \\
\text { displacement by Western } \\
\text { European values and land } \\
\text { management practices }\end{array}$ \\
\hline 5 & $\begin{array}{l}\text { Sub-tropical } \\
\text { subhumid, Acacia } \\
\text { forest and } \\
\text { woodland }\end{array}$ & $\begin{array}{l}60 \% \text { loss due to clearing } \\
\text { and introduction of exotic } \\
\text { pasture grasses, weeds, then } \\
\text { small-scale recovery by } \\
\text { Acacia regrowth }\end{array}$ & $\begin{array}{l}\text { Various regulations that required } \\
\text { clearing by land owners }\end{array}$ & $\begin{array}{l}\text { Domestic and international } \\
\text { demand for grains, meat } \\
\text { and wool }\end{array}$ & $\begin{array}{l}\text { Broad-scale mechanical } \\
\text { clearing, cropping and exotic } \\
\text { pasture systems, domestic } \\
\text { livestock and fencing }\end{array}$ & $\begin{array}{l}\text { Unknown impact of } \\
\text { climate variation }\end{array}$ & $\begin{array}{l}\text { Total indigenous } \\
\text { displacement by Western } \\
\text { European values and land } \\
\text { management practices }\end{array}$ \\
\hline 6 & $\begin{array}{l}\text { Sub-tropical moist, } \\
\text { lowland rainforest }\end{array}$ & $\begin{array}{l}60 \% \text { loss due to land } \\
\text { clearing and conversion to } \\
\text { exotic pastures, colonisation } \\
\text { by a woody weed, then } \\
\text { significant recovery due to } \\
\text { active restoration }\end{array}$ & $\begin{array}{l}\text { Various regulations that required } \\
\text { clearing by land owners, then } \\
\text { initiation of restoration of native } \\
\text { vegetation for water catchment } \\
\text { and local eco-tourism values }\end{array}$ & $\begin{array}{l}\text { Domestic and international } \\
\text { demand for sub-tropical } \\
\text { timbers, then domestic } \\
\text { demand for dairy products }\end{array}$ & $\begin{array}{l}\text { Fencing for intensive dairy } \\
\text { production, then } \\
\text { development of the science } \\
\text { and practice of } \\
\text { ecological restoration }\end{array}$ & $\begin{array}{l}\text { An area of less climatic } \\
\text { variation than } \\
\text { inland Australia }\end{array}$ & $\begin{array}{l}\text { Total indigenous } \\
\text { displacement by Western } \\
\text { European values and land } \\
\text { management practices }\end{array}$ \\
\hline
\end{tabular}


Table 3. Cont.

\begin{tabular}{|c|c|c|c|c|c|c|c|}
\hline $\begin{array}{l}\text { Case } \\
\text { Study }\end{array}$ & $\begin{array}{l}\text { Agro-Climatic } \\
\text { Zone and } \\
\text { Reference } \\
\text { Vegetation } \\
\end{array}$ & $\begin{array}{c}\text { Vegetation Condition } \\
\text { Dynamics (Status Score } \\
\text { Change Relative to } \\
\text { Reference State) } \\
\end{array}$ & Government Policies & Markets & Technological Changes & Climate Variation & Cultural \\
\hline 7 & $\begin{array}{l}\text { Tropical warm } \\
\text { season wet, } \\
\text { eucalypt open } \\
\text { woodland }\end{array}$ & $\begin{array}{l}50 \% \text { loss due to livestock } \\
\text { and feral herbivore grazing } \\
\text { with modest recovery due } \\
\text { to improved grazing } \\
\text { management and increasing } \\
\text { woody cover due to } \\
\text { climate change }\end{array}$ & $\begin{array}{l}\text { Government-managed livestock } \\
\text { reserve, and subsidies for } \\
\text { artificial watering points and } \\
\text { fencing, then R\&D into improved } \\
\text { range management }\end{array}$ & $\begin{array}{l}\text { Domestic and particularly } \\
\text { international demand, } \\
\text { including live cattle exports }\end{array}$ & $\begin{array}{l}\text { Artificial watering points } \\
\text { (bores), then fencing to } \\
\text { improve grazing } \\
\text { management, improved roads } \\
\text { and transport, introduction of } \\
\text { Bos indicus breeds of cattle }\end{array}$ & $\begin{array}{l}\text { Large seasonal fluctuations } \\
\text { in rainfall affecting livestock } \\
\text { and feral herbivore } \\
\text { numbers, but overall } \\
\text { increasing rainfall over a } \\
\text { longer season }\end{array}$ & $\begin{array}{l}\text { Total indigenous } \\
\text { displacement by Western } \\
\text { European values and land } \\
\text { management practices; a } \\
\text { conditional land claim } \\
\text { was granted in 1990, } \\
\text { enabling continued use of } \\
\text { the area as a } \\
\text { research station }\end{array}$ \\
\hline 8 & $\begin{array}{l}\text { Tropical warm } \\
\text { season moist, } \\
\text { tussock grassland }\end{array}$ & $\begin{array}{l}20 \% \text { loss due to loss of } \\
\text { Indigenous fire regime that } \\
\text { controlled woody cover }\end{array}$ & $\begin{array}{l}\text { National park status declared in } \\
\text { 1938, eventual removal of } \\
\text { domestic and feral goat } \\
\text { grazing pressure }\end{array}$ & $\begin{array}{l}\text { Limited use by domestic } \\
\text { livestock for local } \\
\text { consumption }\end{array}$ & $\begin{array}{l}\text { Aerial incendiaries applied, } \\
\text { but with limited success in } \\
\text { reducing woody cover }\end{array}$ & $\begin{array}{l}\text { Limited impact of } \\
\text { seasonal variations }\end{array}$ & $\begin{array}{l}\text { Total indigenous } \\
\text { displacement by Western } \\
\text { European values and land } \\
\text { management practices }\end{array}$ \\
\hline 9 & $\begin{array}{l}\text { Tropical wet, } \\
\text { vine forest }\end{array}$ & $\begin{array}{l}60 \% \text { loss due to land } \\
\text { clearing, then moderate } \\
\text { recovery by passive and } \\
\text { active restoration }\end{array}$ & $\begin{array}{l}\text { State government land } \\
\text { development policies that } \\
\text { promoted land clearing for dairy, } \\
\text { but more recently, site declared a } \\
\text { nature refuge, providing public } \\
\text { and private benefits }\end{array}$ & $\begin{array}{l}\text { Initially demand for high } \\
\text { value tropical timbers, then } \\
\text { domestic dairy production } \\
\text { and subsequent collapse } \\
\text { due to high costs }\end{array}$ & $\begin{array}{l}\text { Introduction of exotic pasture } \\
\text { grasses and dairy production } \\
\text { system, including fertilizers } \\
\text { and lime, then modest } \\
\text { demand for 'life-style' blocks } \\
\text { of land with new owners } \\
\text { passionate about restoration }\end{array}$ & $\begin{array}{l}\text { Very high annual rainfall } \\
\text { accelerated soil erosion and } \\
\text { fertility decline, though this } \\
\text { rainfall also supported } \\
\text { rapid ecological restoration }\end{array}$ & $\begin{array}{l}\text { Total indigenous } \\
\text { displacement by Western } \\
\text { European values and land } \\
\text { management practices }\end{array}$ \\
\hline 10 & $\begin{array}{l}\text { Dry, eucalypt } \\
\text { woodland }\end{array}$ & $\begin{array}{l}30 \% \text { loss due to timber } \\
\text { harvesting and livestock } \\
\text { grazing, then modest } \\
\text { recovery due to improve } \\
\text { grazing management }\end{array}$ & $\begin{array}{l}\text { Recently purchased by state } \\
\text { government as a proposed } \\
\text { conservation reserve }\end{array}$ & $\begin{array}{l}\text { Global demand for minerals } \\
\text { requiring timber for } \\
\text { smelting, then demand for } \\
\text { meat and wool }\end{array}$ & $\begin{array}{l}\text { Smelting technologies } \\
\text { requiring timber for fuel, } \\
\text { fencing, artificial watering } \\
\text { points, domestic livestock }\end{array}$ & $\begin{array}{l}\text { Periods of drought } \\
\text { requiring artificial sources } \\
\text { of water for livestock } \\
\text { (bores and troughs) }\end{array}$ & $\begin{array}{l}\text { Total indigenous } \\
\text { displacement by Western } \\
\text { European values and land } \\
\text { management practices }\end{array}$ \\
\hline
\end{tabular}




\section{Discussion}

We ambitiously set ourselves the task of describing and understanding circa 250 years of landscape transformation of native ecosystems from case studies in 10 contrasting ago-climatic regions of Australia. We have done so by using VAST, a robust framework and methodology that broadly quantifies changes in native vegetation composition, structure and function. These regionally-distinct case studies demonstrate that the condition of vegetation at key points in time is an emergent property of economic markets, new technologies, the history of settlement, environmental constraints, government policies and programs and the impact of individual land manager's practices and values. These studies illustrate the interaction of people living in, learning from and imperfectly adapting to their environment. We suggest that this systematic application of the VAST framework provides rigorous and consistent information for land use planners, policy makers and land managers to design and apply appropriate interventions to improve the vegetation condition and delivery of a diversity of ecosystem services.

We further discuss the significance of these representative case studies in regards to the importance of multiple scales of interpretation, drivers of change and the importance of recognising the resilience status of a given landscape at a given time. These issues relate to the landscape management principles developed by Sayer and others [5].

\subsection{Emergent Impacts at Multiple Scales}

Understanding how a site is transformed spatially over time provides critical insights for a diversity of stakeholders to address the full spectrum of human impacts observed across modified and fragmented landscapes. The vegetation condition framework we have applied is a site-based concept [2], whereas landscape alteration levels are an emergent property of these finer scale representations of vegetation condition [3]. Levels of landscape alteration represent the aggregate of varying degrees of landscape fragmentation and increasing degrees of site modification [1-3]. A framework for conceptualizing the effects of landscape fragmentation and increasing degrees of site modification and understanding their relevance to management, as shown in Figure 12, has been widely accepted [1]. Each of the 10 case studies described above are set within this framework to illustrate how the 10 case studies are set on a pathway toward increasing modification and fragmentation or have been reset towards a pathway of decreasing modification and fragmentation.

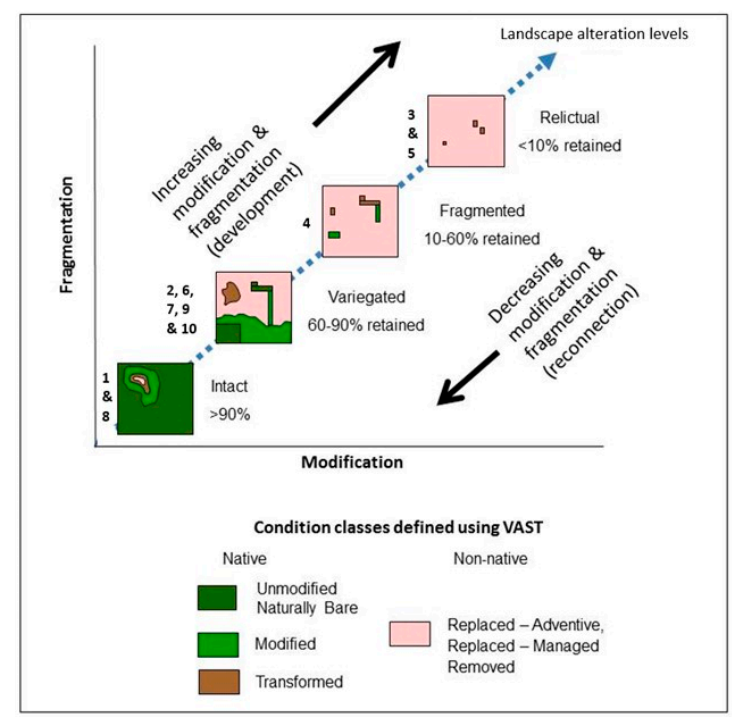

Modified from [21]

Figure 12. Case Studies 1-10 shown in the context of a gradient of landscape alteration levels [3] and VAST classes [2]. 
In the early stages of rural development all case studies occurred in an intact landscape context (within the dark green bars of Figures 2-11). Case Studies 1 and 8 (Figures 2 and 9) represent intact landscapes where greater than $90 \%$ of the mapped extents of vegetation condition are retained comprising three condition classes, unmodified, modified and transformed [2]. The bulk of intact landscapes (Figure 12) are represented by unmodified condition classes. Case Studies 2, 6, 7, 9 and 10 are found in variegated landscapes where $60 \%-90 \%$ of the native vegetation is retained comprising three condition classes, unmodified, modified and transformed [2]. The bulk of the variegated landscapes is comprised of the modified condition class (mid-green bars shown in Figures 2-11). Case Study 4 is found in fragmented landscapes, retaining only $10 \%-60 \%$ of the native vegetation [2]. Case Studies 3 and 5 are found in relictual landscapes, where less than $10 \%$ of the native vegetation is retained [2].

Depicting the 10 case studies using such a landscape model (Figure 12) has a benefit because it provides a policy and planning context for developing and implementing public-private natural resource management programs and partnerships. Particular classes of landscape fragmentation and modification, representing emergent properties of finer scale vegetation condition states, can be identified and prioritised. Such prioritisation can target land managers and local communities with incentives to change land management practices to enhance the indicators of vegetation condition.

This conceptual landscape model can also be used to guide the monitoring and reporting of change at the site and landscape levels to evaluate and track the outcomes of public-private incentive programs. Australian examples of public-private programs that are actively engaging private landholders to relink fragmented landscapes and improve the extent and condition of modified and degraded ecosystems have been described [22]. While such public-private programs vary between regions, we have demonstrated that the case study sites retain varying degrees of resilience in terms of vegetation structure, composition and function. Our results show that many of the broader natural resource management issues pertaining to most of the Australian agro-climatic regions [13] are being confronted and partially resolved at least at the site scale. Many land managers working within these regions are beginning to demonstrate a knowledge of ecosystem dynamics to understand, value and restore vegetation condition and ecosystem resilience [22].

\subsection{Major Drivers of Change}

In all 10 case studies, the main drivers of environmental change are a complex interplay of social, economic and environmental factors impacting how sites and landscapes have been managed and transformed (Table 3). Throughout the history of landscape development and the recovery of landscapes in Australia, state and national governments and, more recently, regional natural resource management bodies have played a major role in influencing how sites and landscapes are managed and transformed. Local communities are one player influencing how the land is managed, albeit a relatively minor player. The exception to this is pattern is Landcare, a community-based movement, which is involved in identifying and resolving natural resource management issues associated with managing land for agricultural productivity [23]. It is worth noting that in developing the chronologies of change in resilience of the 10 case studies, no records of the contribution of the Landcare movement were discovered.

In the early stages of agricultural development in Australia, first British colonial, then state government agencies were largely responsible for commanding or facilitating rural resource exploitation, particularly agricultural and forestry land uses, into areas that were previously all occupied and managed by a diversity of indigenous nations. This was the case regarding the early allocation of land for grazing (e.g., Figures 2 and 4, Figures 5-11); the development of the Brigalow lands for intensive agriculture (e.g., Figure 6); and the allocation of land for forest plantations (e.g., Figure 3).

While there are instances where individuals and local communities moved ahead of the government's ability to control rights and access in developing new areas, as in the case of gold 
fossickers, miners and squatters, colonial, then state governments have generally initiated and controlled access to new areas for agricultural development. For examples where individuals and local communities occupied, managed and transformed landscapes, it can be argued that their impacts were either low and short in duration, as in the case of squatters, or high impact, but confined to small areas, as in the case of mining.

Arguably, over the longer term, market forces and technologies have had a much greater impact on how the land was managed and transformed. Revenue gained from domestic and export sales of agricultural, timber and mining products has been used to apply increasingly sophisticated technologies (e.g., from axes to bulldozers) to modify the vegetation structure, composition and function of sites and landscapes.

\subsection{Resilience}

Collectively, the impact of land management practices and technologies that are market driven or promoted by government policies (e.g., subsidies) has profoundly reduced the vegetation condition and the ecosystem resilience across much of Australia [4,21]. This is particularly the case where intensive agriculture and forestry have removed and replaced the native overstorey or replaced the understorey structure and composition with exotic trees, pastures and crops (e.g., Figures 3-5, 7 and 10). Intensive agriculture and forestry have modified key functional criteria of soil hydrology, soil nutrients, soil structure, soil biology, the natural disturbance regime and the reproductive potential of the plant community (Table 1). These ecosystem changes have, at least in the short term (decades), promoted higher levels of economic productivity than would otherwise be the case under a cover of native vegetation. For example, applications of superphosphate (e.g., Figures 4 and 5) have been used to modify the soil nutrients to promote plant productivity; mechanical cultivation has been used to reduce soil bulk density (soil compaction) and improve rainfall infiltration and water holding capacity. Clearing, prolonged cultivation and the application of herbicides have been used to limit the regrowth of native vegetation to promote agricultural crops and pastures. However, this prolonged disturbance has reduced the natural regenerative capacity of native vegetation to the point that active and costly restoration of native vegetation is now required (e.g., Figures 4 and 10).

In some case studies, market forces, government policies or individual landholder values have changed such that agricultural intensification has been reduced. This has had profound and positive impacts on stimulating natural (spontaneous) regeneration and improving vegetation condition, but only in especially those ecosystems that have retained high levels of resilience. This is the case with the cessation of particular rural industries, e.g., dairying (Figures 7 and 10), pine plantations (e.g., Figure 3) or livestock grazing (e.g., Figures 2 and 9). Cessation of these industries has at least modestly increased the structure, composition and function towards reference states of the native vegetation. The exception was Case Study 8 (Figure 9), where the cessation of domestic and feral livestock grazing has not resulted in increases in vegetation condition towards the pre-European reference state because an alternate reference state (woody cover) has been adopted as a goal of government conservation management.

To a lesser extent, where the land use has been maintained, but the intensity of land management practices has been reduced, there has been a significant increase in the indicators of vegetation condition. For example, within Case Study 4 (Figure 5), a conventional farming system has been replaced with rotational grazing and low intensity cropping into native pasture, which has significantly increased vegetation structure and regenerative capacity, but has not increased the species composition of this formally wooded landscape. In Case Study 7 (Figure 8), grazing pressure by cattle and feral donkeys has been reduced, but not eliminated, resulting in a significant gain in the regenerative capacity of the natural grass pasture, but little influence on vegetation structure and composition. Similarly, for Case Study 10 (Figure 11), fencing and numerous artificial watering points have resulted in less intensive sheep and cattle grazing, stimulating a modest recovery of regenerative capacity, but little impact on vegetation composition and structure. 
All of the case studies exhibited dynamic responses reflecting the interaction between natural and anthropogenic processes; hence, each resilience assessment is time bound [4]. The above case studies can be ordered from highest to lowest, based on the current resilience and management regimes, that is the relative difference between the reference state and recovery of the transformation index. Case studies shown in Figures 2, 7, 9 and 11 are sites that have the highest resilience (80-100\%), Figures 4 and 10 with mid-range resilience (60-80\%) and Figures 3, 5, 6 and 8 with the lowest resilience (40-60\%). This kind of analysis helps to diagnose and understand the effects of land management practices on the response of the plant community as represented by the trajectories of the 22 indicators (Table 1 ) over time.

This analysis of resilience helps to develop prognoses based on the current trend of the condition index scores for the site relative to timing and likely the effectiveness of management interventions; for example, identifying sites that have moderate to high resilience (e.g., high regenerative capacity, Figure 7) that are amenable to passive strategies, such as reduced grazing and weed control to allow natural tree regeneration, which is usually far less expensive than active tree planting. In contrast, active and expensive restoration practices should be targeted to sites that have been recognised to have lost their regenerative capacity, e.g., Figure 4.

\subsection{Changing Values and Attitudes}

Changing social values and attitudes of individuals, communities and governments over the past 25 years or so have resulted in the improvement in vegetation condition within most of the examined case studies. We have documented diverse relationships between public land use policy and planning, land manager's practices and the responses of plant communities over time. These results indicate that in many cases, there are complex relationships between government policy, local communities and private land managers in regards to how sites are managed. For example, the Queensland Government's decision in the 1980s not to reinstate a fire management regime appropriate for restoring the reference state on North Molle Island (Imperata and Themeda tussock grassland) (Figure 9) was strongly influenced by park visitor surveys regarding community concerns over the burning vegetation on the islands in the Great Barrier Reef National Park [24-28]. Likewise, the Victorian Government decisions to control and remove grazing of cattle and sheep from the Bogong High Plains, Victoria (Figure 2), in the 1960s was strongly influenced by an increasing community awareness and concern of the impacts of grazing on alpine vegetation. This government decision was also influenced by increasing recreational demands for access to natural areas, increasing concerns about loss of biodiversity and adverse impacts on soil erosion and water harvesting [29,30]. Equally, the Australian Capital Territory decision not to re-establish a pine plantation at Blundell's flat (Figure 3), in the mid-2000s, was strongly influenced by community concerns over the likelihood of further wildfires; its severity appeared to be influenced by the flammability of pine plantations. In addition, pine plantations were not re-established in a major water catchment because of community concerns over the effect of plantations on water quality and quantity [31].

These three examples illustrate the roles community and government have in influencing changes in vegetation structure, composition and function. While the spatial extent of these case studies is small, they represent more broadly changes in community attitudes and values that can be observed well beyond these case studies. Changing community attitudes and values have seen an increased demand for the creation and conservation of natural areas resulting in the removal of grazing from almost all formally protected public and private nature reserves across Australia. In the early colonial development of Australia, the prevailing community expectation was of privately managed rural enterprises supported by government policies and incentives to support food and timber industries and the national economy. Since about the late 1930s, community attitudes and values have moved away from solely supporting agricultural and forestry enterprises, towards conserving natural areas for public benefits and services. 


\section{Conclusions}

We hope to have demonstrated that representative and systematic site-level assessments of vegetation condition dynamics over hundreds of years can provide valuable insights into how landscapes have been altered. This long-term perspective can then be used to help identify interventions to meet current and future community values and expectations. We have tried to demonstrate that this kind of rapid, but repeatable analysis can help answer such questions as: What is the condition of the native vegetation at a site relative to an accepted national standard? How can one assess and report consistently and at multiple scales the condition of ecosystems resulting from management interventions? As a land manager, how can this knowledge be used to improve the condition of a site or landscape? These are questions that need a broad, consistent and historical approach to answering.

We suggest that the kind of visual presentation of the results shown in this paper allows policy makers and land managers to quickly recognise and understand how complex socio-ecological processes can affect ecosystem dynamics and services. Such graphically-presented information should also be useful for monitoring, analysing and reporting the effects of land management practices at the selected sites [32,33], as well as for regional accounts of native vegetation condition [34].

We have tried to demonstrate that a systemic approach to documenting and explaining the historical dynamics of vegetation composition, structure and regenerative capacity is useful for tracking and evaluating the diverse drivers of change. Understanding these drivers is critical to developing an ecological and social understanding of how vegetation condition and ecosystem services at multiple scales can be best managed into the future.

Supplementary Materials: The following are available online at www.mdpi.com/2073-445X/5/4/40/s1, Table S1 List of 10 sites assessed using the VAST-2 criteria and indicators of structure, species composition and function (Table 1) showing the associated agro-climate regions, bioregions and plant communities, Table S2. Descriptions of agro-climatic regions, Case Studies 1-10.

Acknowledgments: We thank each of the land managers and researchers who provided detailed records on the history of the management of each site. Their contribution has enabled the effects of land management and the responses of the respective plant communities to become part of the public record, thus demonstrating the value of compiling and integrating qualitative spatial and temporal information with quantitative sources of information.

Author Contributions: Richard Thackway and David Freudenberger conceived and designed the experiments; performed the experiments; analysed the data; contributed reagents/materials/analysis tools; and wrote the paper.

Conflicts of Interest: The authors declare no conflict of interest. The founding sponsors had no role in the design of the study; in the collection, analyses, or interpretation of data; in the writing of the manuscript, and in the decision to publish the results.

\section{References}

1. McIntyre, S.; Hobbs, R.J. Human impacts on landscapes: Matrix condition and management priorities. In Nature Conservation 5: Nature Conservation in Production Environments: Managing the Matrix; Craig, J.L., Mitchell, N., Saunders, D.A., Eds.; Surrey Beatty and Sons: Chipping Norton, Australia, 2000; pp. 301-307.

2. Thackway, R.; Lesslie, R. Describing and mapping human-induced vegetation change in the Australian landscape. Environ. Manag. 2008, 42, 572-590. [CrossRef] [PubMed]

3. Mutendeudzi, M.; Thackway, R. A Method for Deriving Maps of Landscape Alteration Levels from Vegetation Condition State Datasets; Bureau of Rural Sciences: Canberra, Australia, 2010.

4. Resilience Alliance. Assessing Resilience in Social-Ecological Systems: Workbook for Practitioners, Version 2.0; 2010. Available online: http://www.resalliance.org/3871.php (accessed on 31 January 2016).

5. Sayer, J.; Sunderland, T.; Ghazoul, J.; Pfund, J.L.; Sheil, D.; Meijaard, E.; Venter, M.; Boedhihartono, A.K.; Day, M.; Garcia, C.; et al. Ten principles for a landscape approach to reconciling agriculture, conservation, and other competing land uses. Proc. Natl. Acad. Sci. USA 2013, 110, 8349-8356. [CrossRef] [PubMed]

6. Woollacott, A.; Adcock, M.; Allen, M.; Evans, R.; Mackinnon, A. Overview: The Making of the Modern World (1750-1918); Cambridge University Press: Cambridge, UK, 2010.

7. Mulvaney, D.J. The Prehistory of Australia; Frederick A Praeger: New York, NY, USA, 1969. 
8. Blainey, G. The Story of Australia's People. The Rise and Fall of Ancient Australia; Viking: Melbourne, Australia, 2015.

9. Thackway, R.; Specht, A. Synthesising the effects of land use on natural and managed landscapes. Sci. Total Environ. 2015, 526, 136-152. [CrossRef] [PubMed]

10. Brown, V.A.; Lambert, J.A. Collective Learning for Transformational Change: A Guide to Collaborative Action; Routledge: London, UK; New York, NY, USA, 2013.

11. Yapp, G.; Walker, J.; Thackway, R. Linking vegetation type and condition to ecosystem goods and services. Ecol. Complex. 2010, 7, 292-301. [CrossRef]

12. Schaffer, G.; Levin, N. Mapping human induced landscape changes in israel between the end of the 19 th century and the beginning of the 21th century. J. Landsc. Ecol. 2014, 7, 110-145. [CrossRef]

13. Hobbs, R.J.; McIntyre, S. Categorizing Australian landscapes as an aid to assessing the generality of landscape management guidelines. Glob. Ecol. Biogeogr. 2005, 14, 1-15. [CrossRef]

14. Hutchinson, M.F.; McIntyre, S.; Hobbs, R.J.; Stein, J.L.; Garnett, S.; Kinloch, J. Integrating a global agro-climatic classification with bioregional boundaries in Australia. Glob. Ecol. Biogeogr. 2005, 14, 197-212. [CrossRef]

15. Williams, J.; Hook, R.A.; Hamblin, A. Agro-Ecological Regions of Australia, Methodologies for Their Derivation and Key Issues in Resource Management; CSIRO Land and Water: Canberra, Australia, 2002.

16. Köppen, W. Die Klimate der Erde; De Gruyter: Berlin, Germany, 1923.

17. Noss, R.F. Indicators for Monitoring Biodiversity: A Hierarchical Approach. Conserv. Biol. 1990, 4, 355-364. [CrossRef]

18. Tropical Savannas Cooperative Research Centre. Savanna Explorer Northern Australian Information Service. Retrieved from The Population of Savanna Australia: (n.d.). Available online: http:/ /www.savanna.org.au/ all/economic.html (accessed on17 April 2016).

19. Fensham, R.J.; Fairfax, R.J.; Archer, S.R. Rainfall, land use and woody vegetation cover change in semi-arid Australian savanna. J. Ecol. 2005, 93, 596-606. [CrossRef]

20. Thackway, R. Tracking Anthropogenic Influences on the Condition of Plant Communities at Sites and Landscape Scales; Almusaed, A.Z., Ed.; Landscape Ecology: Rijeka, Croatia, 2016.

21. Yapp, G.A.; Thackway, R. Responding to change-Criteria and indicators for managing the transformation of vegetated landscapes to maintain or restore ecosystem diversity. In Biodiversity in Ecosystems_Linking Structure and Function; Blanco, J.A., Ed.; InTech: Rijeka, Croatia, 2015.

22. Fitzsimons, J.; Pulsford, I.; Wescott, G. (Eds.) Linking Australia's Landscapes, Lessons and Opportunities from Large-Scale Conservation Networks; CSIRO Publishing: Collingwood, Australia, 2013.

23. Brown, V.A. Landcare Languages: Talking to Each Other about Living with the Land; National Landcare Program, Department of Primary Industry: Canberra, Australia, 1995.

24. Queensland Herbarium. Regional Ecosystem Description Database (REDD); Version 9.0; Queensland Department of Science, Information Technology and Innovation: Brisbane, QLD, Australia, 2015. Available online: https:/ /environment.ehp.qld.gov.au/regional-ecosystems/ (accessed on 17 April 2016).

25. McDonald, K.; Atherton, Queensland. Personal communication, 2016.

26. Stanton, P.; Redlynch, Queensland. Personal communication, 2015.

27. Department of National Parks, Recreation, Sport and Racing. Whitsunday Islands National Parks and Adjoining State Waters Management Statement 2013; Department of National Parks, Recreation, Sport and Racing, Queensland Government, 2013. Available online: http://www.nprsr.qld.gov.au/managing/plansstrategies/statements/pdf/whitsunday-islands.pdf (accessed on 15 May 2016).

28. Stanton, P.; Stanton, D.; Stott, M.; Parsons, M. Fire exclusion and the changing landscape of Queensland's Wet Tropics Bioregion 1. The extent and pattern of transition. Aust. For. 2014, 77, 51-57. [CrossRef]

29. Victorian Conservation Trust. Bogong High Plains, Vegetation Map and Guide to Alpine Flora. 1:15,000 Scale. One of a Series. Rocky Valley Sheet Including Falls Creek, Mt Nelse and Mt Cope Areas; Victorian Conservation Trust in Conjuction with the Soil Conservation Service: Melbourne, Australia, 1986.

30. Australian Alps National Parks. Grazing in the Australian Alps. Educational Resource. Available online: https: / theaustralianalps.files.wordpress.com/2013/11/grazing.pdf (accessed on 31 January 2016).

31. Thackway, R. Blundells Flat, Ex-Coupe 424, ACT. Ver. 1. VAST-2: Tracking the Transformation of Australia's Vegetated Landscapes; Australian Centre for Ecological Analysis and Synthesis, University of Queensland: Brisbane, Australia, 2012. 
32. Montreal Implementation Group National Forest Inventory Steering Committee. Australia's State of the Forests Report 2013; Montreal Process Implementation Group for Australia and National Forest Inventory Steering Committee: Canberra, Australia, 2013.

33. Ecosystem Science Long-Term Plan Steering Committee. Foundations for the Future: A Long-Term Plan for Australian Ecosystem Science; Terrestrial Ecosystem Research Network, the Ecological Society of Australia, and the Australian Academy of Science's National Committee for Ecology, Evolution and Conservation: Canberra, Australia, 2014.

34. Sbrocchi, C.; Davis, R.; Grundy, M.; Harding, R.; Hillman, T.; Mount, R.; Possingham, H.; Saunders, D.; Smith, T.; Thackway, R.; et al. Technical Analysis of the Australian Regional Environmental Accounts Trial; Wentworth Group of Concerned Scientists: Sydney, Australia, 2015.

(C) 2016 by the authors; licensee MDPI, Basel, Switzerland. This article is an open access article distributed under the terms and conditions of the Creative Commons Attribution (CC-BY) license (http:/ / creativecommons.org/licenses/by/4.0/). 